\title{
HIPERNATREMIJA INTENSYVIOJOJE TERAPIJOJE
}

\author{
Šarūnas Masys ${ }^{1}$, Dominyka Kaušaitè ${ }^{2}$ \\ ${ }^{1}$ Respublikinè Šiauliu ligonine, ${ }^{2}$ Vilniaus universiteto Medicinos fakultetas
}

Raktažodžiai: hipernatremija, intensyvioji terapija, laisvo vandens trūkumas, hiperosmoliariškumas.

\section{Santrauka}

Hipernatremija - tai būklè, kurios metu natrio koncentracija plazmoje yra didesnè nei $145 \mathrm{mmol} / \mathrm{l}$. Su šia liga dažnai susiduriama intensyviojoje terapijoje. Tyrimo tikslas - atrinkti ir išanalizuoti ekspertų nustatytas ir visuotinai pripažintas hipernatremijos rūšis, diagnostikos bei gydymo rekomendacijas. Literatūros apžvalga atlikta naudojantis PubMed ir Google Scholar mokslinėmis duomenų bazèmis. Naudoti raktažodžiai originalo kalba: hypernatremia, intensive care, lack of free water, hyperosmolarity. Analizei atrinkti laisvai prieinami viso teksto straipsniai anglu kalba, kuriu santrauka ir turinys atitiko tyrimo temą. Tyrimo rezultatai. Hiponatremija dažniausiai susijusi su bendro vandens trūkumu, sutrikusiu troškulio jausmu, negalèjimu savarankiškai pasiekti vandens, retais atvejais gali būti dèl hipertoninių tirpalų skyrimo. Kritiškai sunkios būklès pacientų šios ligos rizika didesnè, nes dažnai savarankiškai negali kontroliuoti išgeriamo vandens kiekio dèl sedacijos, intubacijos, pasikeitusios sąmonès būklès ar dèl vandens apribojimo tam tikrų būklių metu. Hipernatremijos klinikine išraiška priklauso nuo jos atsiradimo laiko ir sunkumo. Būdinga sutrikusi kognityvinè, neuroraumenine funkcija, sunkiais atvejais hemoraginès komplikacijos ir net mirtis. Gydymas orientuotas i laisvo vandens korekciją, siekiant atkurti plazmos osmoliariškumą. Svarbu nustatyti ligą sukèlusią priežastị ir skirti gydymą. Hipernatremijos korekcijos greitis priklauso nuo ligos atsiradimo trukmès, gretutinių ligų. Dažnas natrio koncentracijos matavimas plazmoje yra būtinas užkirsti kelią galimoms komplikacijoms, kurios gali atsirasti dẻl gydymo.

Išvados. Hipernatremija yra dažnai pasireiškianti būklè intensyviojoje terapijoje, susijusi su padidejusiu mirštamumu. Svarbiausia rasti jos priežastị ir skirti gydymą, atkurti skysčių balansą ir koreguoti homeostazę. Sie- kiant išvengti smegenų edemos, natrio korekcija neturètų viršyti $8-10 \mathrm{mmol} / \mathrm{l}$ per 24 valandas.

\section{Ivadas}

Hipernatremija - tai būklè, kurios metu natrio koncentracija plazmoje yra didesné nei $145 \mathrm{mmol} / \mathrm{l}$. Dažniausiai nustatoma žmonėms, kurių sumažèjęs troškulio jausmas, nèra galimybės gauti vandens arba abi priežastys kartu. Ši liga gali paūmèti kritinių būklių metu, kai padidèja netenkamo vandens kiekis. Intensyviojoje terapijoje dažnai pasireiškia dèl prarandamo vandens arba netinkamos vandens korekcijos. Hipernatremija hospitalizavimo i intensyviosios terapijos skyriu metu nustatoma 2-9 proc. pacientu $[1,2]$. Hipernatremija, atsiradusi gydymosi ligoninèje metu, yra nepriklausomas rizikos veiksnys, susijęs su padidejjusiu mirštamumu intensyviosios terapijos skyriuose [2]. Hipernatremija dažniausiai nesusijusi su natrio apykaitos sutrikimu, o susijusi su laisvo vandens deficitu, kuris atsiranda dèl neigiamo gaunamo ir išskiriamo vandens balanso. Retais atvejais ši liga gali būti susijusi su padidejjusiu natrio gavimu, pavyzdžiui, dẻl hipertoninio natrio chlorido. Priklausomai nuo santykio tarp gaunamo natrio ir išskiriamo arba gaunamo vandens, ši liga skirstoma ị hipervoleminę, euvoleminę ir hipovoleminę hipernatremiją.

Tyrimo tikslas - atrinkti ir išanalizuoti ekspertų nustatytas ir visuotinai pripažintas hipernatremijos rūšis, diagnostikos bei gydymo rekomendacijas.

\section{Tyrimo medžiaga ir metodai}

Literatūros apžvalga atlikta remiantis PubMed ir Google Scholar mokslinèmis duomenų bazèmis, atrenkant publikacijas nuo 2015 iki 2021 metų anglų kalba, naudojant raktažodžius originalo kalba: hypernatremia, intensive care, lack of free water, hyperosmolarity.

\section{Tyrimo rezultatai}

Hipovoleminė hipernatremija atsiranda dèl neigiamo vandens balanso, kuris viršija netenkamo natrio kiekị. Dẻl to atsirandanti hipovolemija yra vienas dažniausių reiškinių dèl 
hipernatremijos stacionarizuotiems pacientams [3]. Seduoti, intubuoti, neurologinị deficitą turintys vyresnio amžiaus pacientai negali užtikrinti išgeriamo vandens kiekio [4,5]. Padidèjęs laisvo vandens netekimas sukelia hipernatremiją. Karščiavimas yra dažnas veiksnys, kuris paskatina hipovoleminès hipernatremijos atsiradimą $[2,3,6]$. Viduriavimas - kita priežastis, dèl kurios prarandamas hipotoninis vanduo. Jis gali būti sukeltas infekcijos, laktuliozès ar kitų veiksnių. Intensyviojoje terapijoje dažnai naudojami kilpiniai diuretikai, ypač manitolis, sukelia osmotinę diurezę, kurios metu organizmas netenka vandens, o kartu su vandeniu ir natrio [2,7].

Euvoleminė hipernatremija pasireiškia, kai vandens balansas yra neigiamas, o druskų - normalus. Sumažeję̨s vandens vartojimas yra būtinas euvoleminès hipernatremijos veiksnys [8]. Pacientų, kurių vandens vartojimas sumažèjęs (kūdikiai, senyvo amžiaus žmonès), šlapimo koncentracija yra normali arba padidejusi. Hipernatremiją patiria sergantieji necukriniu diabetu, kai sumažejęs vandens vartojimas (pavyzdžiui, kritiškai sunkios būklès metu). Ši liga dažnai pasireiškia esant vèlyvos fazès septiniam šokui, traumos sukeltai smegenų pažaidai.

Hipervoleminė hipernatremija dažniausiai yra jatrogeninès kilmès $[9,10]$. Intensyviojoje terapijoje hipervoleminè hipernatremija dažnai susijusi su gausia skysčių korekcija izotoniniu natrio chlorido tirpalu arba su hipokalemijos korekcija, kai naudojami hipertoniniai kalio chlorido tirpalai. Hipernatremija gali būti sukelta, kai siekiama sumažinti intrakranijinę hipertenziją, naudojant hipertoninį natrio chlorido tirpalą arba natrio bikarbonato tirpalą [11,12]. Kita šios būklès priežastis gali būti sumažejusi natriurezè dèl sumažẻjusio efektyvaus plazmos tūrio ir glomerulų filtracijos greičio [13].

Diagnostika ir gydymas. Ligai būdingi nespecifiniai simptomai. Gali pasireikšti letargija, sumišimas, pykinimas, vėmimas, bendras silpnumas, sunkiais atvejais - traukuliai ir koma. Židininè neurologinè simptomatika nebūdinga. Pirminis gydymas turètų būti paremtas principu ABC (angl. air way; breathing; circulation). Šoko ar hipoperfuzijos metu pirmiausiai turetu būti skiriamas izotoninis natrio chlorido tirpalas, remiantis hemodinaminiais parametrais [14]. Priežasties, sukèlusios hipernatremiją, nustatymas ir gydymas turètų būti taikomas greta pirminio gydymo. Volemijos statuso ištyrimas yra vienas iš esminių dalykų, kuris nulemia gydymo taktikos parinkimą [4,5].

Greita natrio koncentracijos korekcija gali sukelti traukulius ir mirti $[13,15-17]$, todèl rekomenduojamas natrio korekcijos greitis turètų neviršyti $0,5 \mathrm{mmol} / \mathrm{l} / \mathrm{h}$ [13]. Plazmos natrio koncentracija neturètų būti koreguojama daugiau nei $8-10 \mathrm{mmol} / \mathrm{l}$ per 24 valandas. Priešingai, ūminè hipernatremija turètų būti koreguota nuo 24 iki 48 valandų.

\section{Išvados}

1. Hipernatremija yra dažnai pasireiškianti būklè intensyviojoje terapijoje, susijusi su padidejjusiu mirštamumu.

2. Svarbiausia rasti priežastị ir skirti gydymą, atkurti skysčių balansą ir koreguoti homeostazę.

3. Siekiant išvengti smegenų edemos, natrio korekcija neturètų viršyti $8-10 \mathrm{mmol} / \mathrm{l}$ per 24 valandas.

\section{Literatūra}

1. Qian Q. Hypernatremia. Clin J Am Soc Nephrol 2019;14(3):432-4. https://doi.org/10.2215/CJN.12141018

2. Braun MM, Barstow CH, Pyzocha NJ. Diagnosis and management of sodium disorders: hyponatremia and hypernatremia. Am Fam Physician 2015; 91(5):299-307.

3. Chauhan K, Pattharanitima P, Patel N, Duffy A, Saha A, Chaudhary K, et al. Rate of Correction of Hypernatremia and Health Outcomes in Critically Ill Patients. Clin J Am Soc Nephrol 2019; 14(5):656-63.

https://doi.org/10.2215/CJN.10640918

4. Sterns RH. Evidence for Managing Hypernatremia. Clin J Am Soc Nephrol 2019; 14(5):645-7.

https://doi.org/10.2215/CJN.02950319

5. Wolff A, Stuckler D, McKee M. Are patients admitted to hospitals from care homes dehydrated? A retrospective analysis of hypernatraemia and in-hospital mortality. J R Soc Med 2015; 108(7):259-65.

https://doi.org/10.1177/0141076814566260

6. Ranjan R, Lo SC-Y, Ly S, Krishnananthan V, Lim AKH. Progression to Severe Hypernatremia in Hospitalized General Medicine Inpatients: An Observational Study of Hospital-Acquired Hypernatremia. Medicina (Kaunas). 2020; 56(7):E358.

https://doi.org/10.3390/medicina56070358

7. Hu B, Han Q, Mengke N, He K, Zhang Y, Nie Z, et al. Prognostic value of ICU-acquired hypernatremia in patients with neurological dysfunction. Medicine (Baltimore) 2016; 95(35):e3840. https://doi.org/10.1097/MD.0000000000003840

8. Rugg C, Ströhle M, Schmid S, Kreutziger J. The Link between Hypermetabolism and Hypernatremia in Severely Burned Patients. Nutrients 2020; 12(3):774.

https://doi.org/10.3390/nu12030774

9. Distenhreft JIQ, Vianna JGP, Scopel GS, Ramos JM, Seguro AC, Luchi WM. The role of urea-induced osmotic diuresis and hypernatremia in a critically ill patient: case report and literature review. J Bras Nefrol 2020; 42(1):106-12.

https://doi.org/10.1590/2175-8239-jbn-2018-0226

10. Quinn JW, Sewell K, Simmons DE. Recommendations for active correction of hypernatremia in volume-resuscitated shock or sepsis patients should be taken with a grain of salt: A systematic review. SAGE Open Med 2018; 6:2050312118762043.

https://doi.org/10.1177/2050312118762043

11. Olsen MH, Møller M, Romano S, Andersson J, Mlodzinski E, 
Raines NH, et al. Association Between ICU-Acquired Hypernatremia and In-Hospital Mortality: Data From the Medical Information Mart for Intensive Care III and the Electronic ICU Collaborative Research Database. Crit Care Explor 2020; 2(12):e0304.

https://doi.org/10.1097/CCE.0000000000000304

12. Mangat HS. Hypertonic saline infusion for treating intracranial hypertension after severe traumatic brain injury. Crit Care 2018; $22: 37$. https://doi.org/10.1186/s13054-018-1963-7

13. Asehnoune K, Lasocki S, Seguin P, Geeraerts T, Perrigault PF, Dahyot-Fizelier C, et al. Association between continuous hyperosmolar therapy and survival in patients with traumatic brain injury - a multicentre prospective cohort study and systematic review. Crit Care 2017; 21:328.

https://doi.org/10.1186/s13054-017-1918-4

14. Morkos M, Fam M, Goel M, Hart P, Kazlauskaite R. Protracted acute hypervolemic hypernatremia unmasked after vasopressin therapy: case report, literature review and proposed algorithmic approach. Aace Clin Case Rep 2018; 5(2):e95-8. https://doi.org/10.4158/ACCR-2018-0363

15. Hypernatremia Guidelines: Guidelines Summary [Internet]. [cited 2021 Jul 13]. Available from: https://emedicine.medscape. com/article/241094-guidelines

16. Seay NW, Lehrich RW, Greenberg A. Diagnosis and Management of Disorders of Body Tonicity-Hyponatremia and Hypernatremia: Core Curriculum 2020. Am J Kidney Dis 2020; 75(2):272-86. https://doi.org/10.1053/j.ajkd.2019.07.014

17. Sonani B, Naganathan S, Al-Dhahir MA. Hypernatremia. In: StatPearls [Internet]. Treasure Island (FL): StatPearls Publishing 2021 [cited 2021 Jul 13]. Available from: http://www.ncbi. nlm.nih.gov/books/NBK441960/

18. Hypernatremia \& dehydration in the ICU [Internet]. EMCrit Project. [cited 2021 Jul 13]. Available from: https://emcrit.org/

\section{IBCC/HYPERNATREMIA/HYPERNATREMIA IN INTENSIVE CARE \\ S. Masys, D. Kaušaitè}

Keywords: hypernatremia, intensive care, lack of free water, hyperosmolarity.

Summary

Hypernatremia is a condition in which the plasma sodium concentration is greater than $145 \mathrm{mmol} / 1$. This disease is often encountered in intensive care. It is usually associated with a general lack of water, impaired feeling of thirst, inability to reach the water on their own, and in rare cases may be due to the administration of hypertonic solutions. Critically ill patients are at higher risk of developing the disease because they are often unable to control the amount of water they drink on their own, due to sedation, intubation, altered state of consciousness, or water restriction during certain conditions. The clinical manifestation of hypernatremia depends on the time and severity of its occurrence. It is characterized by impaired cognitive, neuromuscular function, in severe cases hemorrhagic complications and even death. Treatment is focused on free water correction to restore plasma osmolarity, as well as identification and treatment of the cause of the disease. The speed of treatment of hypernatremia depends on the duration of the disease, concomitant diseases. Frequent measurement of plasma sodium levels is necessary to prevent possible complications that may arise from treatment. This literature review is intended to review the etiology of hypernatremia, the peculiarities of treatment in intensive care. The aim of this article is to review the literature on the etiology of hypernatremia and treatment recommendations in intensive care.

Correspondence to: dominyka.kausaite@gmail.com

Gauta 2021-05-18 